\title{
A survey of grassland Asilidae (Diptera) at Jacana Eco Estate, Hilton, South Africa
}

\author{
Jason G. H. Londt ${ }^{1,2}$ \\ I KwaZulu-Natal Museum, P. Bag 9070, Pietermaritzburg, 3200, South Africa 2 School of Biological \& \\ Conservation Sciences, University of KwaZulu-Natal, Pietermaritzburg, South Africa \\ Corresponding author: Jason G. H. Londt (robber4afr@telkomsa.net)
}

Academic editor: Torsten Dikow | Received 7 February 2020 | Accepted 19 March 2020 | Published 24 April 2020

http://zoobank.org/4B0D3924-3E01-4D3A-9EDC-F6CBA335159F

Citation: Londt JGH (2020) A survey of grassland Asilidae (Diptera) at Jacana Eco Estate, Hilton, South Africa. African Invertebrates 61(1): 29-48. https://doi.org/10.3897/AfrInvertebr.61.50895

\begin{abstract}
A year-long survey of grassland Asilidae was undertaken at Jacana Eco Estate, Hilton, KwaZulu-Natal, South Africa. The following 18 species of Asilidae, in alphabetical order, were encountered: Caenoura annulitarsis (Loew, 1858), Damalis monochaetes Londt, 1989, Dasophrys androclea (Walker, 1849), Dasophrys fortis Londt, 1981, Dasophrys tarsalis (Ricardo, 1920), Dasophrys umbripennis Londt, 1981, Dysclytus firmatus (Walker, 1857), Euscelidia vallis Dikow, 2003, Ischiolobos mesotopos Londt, 2005, Leptogaster sp., Melouromyia natalensis (Ricardo, 1919), Microstylum sp., Neolophonotus hirsutus (Ricardo, 1920), Neolophonotus variabilis Londt, 1986, Neolophonotus wroughtoni (Ricardo, 1920), Pegesimallus bicolor (Loew, 1858), Pegesimallus pedunculatus (Loew, 1858), Rhipidocephala obscurata Oldroyd, 1966. Their flight periods were recorded and tabulated. The variety and numbers encountered suggest that the grassland invertebrate community is healthy and that the grassland is worthy of its conservation status.
\end{abstract}

\section{Keywords}

Africa, Asilidae, Grassland, seasonal incidence, conservation

\section{Introduction}

Grassland is one of South Africa's most neglected and threatened biomes. Human development has placed the biome at great risk of being severely compromised (Van Oudtshoorn 1999, Van Wyk and Smith 2001). Very few studies aimed at understanding the many invertebrates associated with the savannah biome have been undertaken.

Copyright Jason G. H. Londt. This is an open access article distributed under the terms of the Creative Commons Attribution License (CC BY 4.0), which permits unrestricted use, distribution, and reproduction in any medium, provided the original author and source are credited. 
An understanding of the role that predatory insects, like Assassin Flies (Diptera: Asilidae), play within grassland invertebrate communities, is likely to contribute towards a greater appreciation of the complexity of this threatened biome and, hopefully, lead to the implementation of effective management practices.

In 2018, it came to the author's attention that a relatively small housing development was taking place in Hilton, a small village on the outskirts of Pietermaritzburg, in the midlands of KwaZulu-Natal, South Africa. The developers of what is now called the Jacana Eco Estate, the Kotze Family Trust, had been given permission to build a number of houses on Portion 25 of Erf 330 Hilton. The area, which is dominated by grassland, is currently bordered by a few houses and an area that used to be a pine plantation. The grassland had been minimally impacted by human activity and was, therefore, considered one of the better pieces of relatively unspoilt grassland in the area. An Environmental Management Plan had been compiled in 2016 by Environmental Planning Services, Glenwood, Durban and this was to be implemented throughout the development phase and subsequently by the owners of houses built on the estate and adjacent to the grassland.

Having undertaken a survey of grassland Asilidae at Queen Elizabeth Park, in Pietermaritzburg (Londt 2002b), which had produced some interesting and unique observations, it was decided to approach the developers for permission to conduct a similar year-long survey at Jacana Eco Estate, as it was believed that this could add to an understanding that the area should be properly conserved for future generations.

When approached, Mr Paul Kotze, of the Kotze Family Trust, kindly gave permission for weekly sampling of Asilidae to commence at the start of 2019. The results of this year-long survey are here presented.

\section{Jacana Eco Estate}

The Jacana Eco Estate, hereafter merely called Jacana, is situated at ca. 29³2'35"S, $30^{\circ} 17^{\prime} 38^{\prime \prime} \mathrm{E}$ (Fig. 1). The grassland area, which is divided into two parts, or fields, separated by an access road linking the entrance to the estate with the houses built along its north-western boundary, slopes downwards from the north-eastern boundary (altitude $1132 \mathrm{~m}$ asl) to the south-western boundary (altitude $1107 \mathrm{~m}$ asl). The highest part of the grassland is some $25 \mathrm{~m}$ higher than the lowest section. The upper field is larger than the lower field and more exposed to wind. The lower field is bordered by housing and trees outside the estate and is somewhat sheltered from wind. The lower field is also more inundated by alien invasive plants.

While a fairly comprehensive Biodiversity Assessment had been carried out by Dr JH Grobler in October 2007 of the 'Bracken Ridge Development (Hilton Erf. 330) Pietermaritzburg' (Grobler 2007), which included the area now separated off as Jacana, this was confined to a zoological assessment and did not cover botanical matters. However, a copy of an undated 'Vegetation Report', conducted during or after 2015 by Roderick Collett, a lecturer in Veld Management at Cedara College, was given to me by Paul Kotze that contains a list of grasses found in the area (Table 1). 


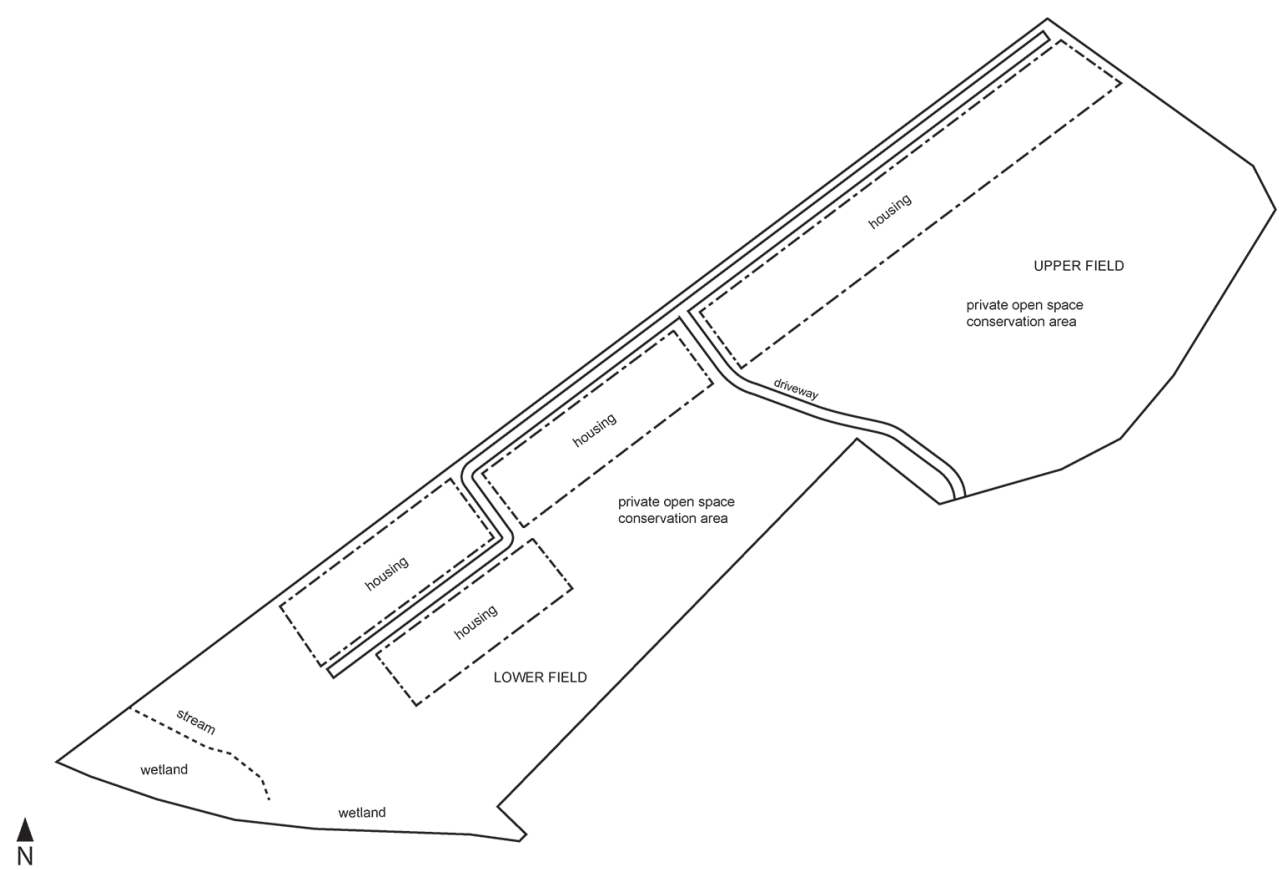

Figure I. Jacana Eco Estate showing area of conserved grassland separated by an access road into upper and lower fields. Map: B. Muller.

Table I. Grasses likely to be encountered at Jacana Eco Estate as listed by Roderick Collett (alphabetically within categories), together with common names as provided by Van Oudtshoorn (1992) and definitions of categories.

\begin{tabular}{l|l}
\hline Increaser I & $\begin{array}{l}\text { Alloteropsis semialata (Black-seed Grass); Digitaria tricholaenoides (Purple Finger Grass); Eulalia } \\
\text { villosa (Golden Velvet Grass); Setaria nigrirostris (Black-seed Bristle Grass); Trachypogon spicatus } \\
\text { (Giant Spear Grass); Tristachya leucothrix (Hairy Trident Grass) }\end{array}$ \\
\hline Decreaser & $\begin{array}{l}\text { Brachiaria serrata (Velvet Signal Grass); Diheteropogon amplectens (Broad-leaved Bluestem); } \\
\text { Monocymbium ceresiiforme (Boat Grass); Themeda triandra (Red Grass) }\end{array}$ \\
\hline Increaser 11a & $\begin{array}{l}\text { Eragrostis capensis (Heart-seed Love Grass); Harpochloa falx (caterpillar Grass); Heteropogon } \\
\text { contortus (Spear Grass) }\end{array}$ \\
\hline Increaser 11b & $\begin{array}{l}\text { Eragrostis curvula (Weeping Love Grass); Eragrostis plana (Tough Love Grass); Eragrostic racemosa } \\
\text { (Narrow Heart Love Grass); Hyparrhenia hirta (Common Thatching Grass); Sporobolus africanus } \\
\text { (Ratstail Dropseed) }\end{array}$ \\
\hline Increaser 11c & Microchloa caffra (Pincushion Grass); Paspalum scrobiculatum (Veld Paspalum) \\
\hline Increaser 111 & $\begin{array}{l}\text { Aristida junciformis (Gongoni Three-awn); Diheteropogon filifolius (Thread-leaved Bluestem); } \\
\text { Elionurus muticus (Wire Grass) }\end{array}$ \\
\hline
\end{tabular}

\section{Definitions:}

Decreaser: A dominant grass in good, well-managed veld that will decrease under any form of mismanagement, such as severe disturbance, untimely burn, overgrazing or under-utilisation.

Increaser: A grass species that will increase under any type of mismanagement or disturbance.

There are two types of increasers: Increaser I: A grass species that will increase under conditions of underutilisation or understocking or on an area which is selectively undergrazed. Increaser II: A grass species that is dominant in poor veld or that will increase under any form of overgrazing or disturbance.

There are three types of Increaser IIs: Increaser IIa: A species that increases with mild overgrazing. Increaser IIb: A species that increases with moderate overgrazing. Increaser IIc: A species that increases with severe overgrazing. 
In addition to the above documentation, I was given a copy of an unpublished Environmental Management Plan for Hilton Green, compiled in 2016 by Environmental Planning Services (197 Masizi Kunene Road, Glenwood, Durban), relating to Portion 25 of Erf 330, Hilton. While this document was intended to guide the developer during the building phase of Jacana, it contained no environmental information relating specifically to the proposed Eco Estate.

While undertaking the asilid survey, the grassland was burned in keeping with conventional management practices. The upper part of the lower field, below the access road, was burned at the end of August (week 35) while the lower part of this area was burned a week later, during the first week of September (week 36). The entire upper field, above the access road, was then burned in early October (week 41). Although some flowering plants, other than grasses, were encountered throughout the survey, many appeared soon after these burns. The following list of plants, photographed at Jacana, is by no means exhaustive, but is provided in order to stimulate further interest in what the Eco Estate has to offer botanically. Where known, common names, as recorded by Pooley (1998), are provided in brackets: Acalypha punctata (Sticky Brooms and Brushes), Afroaster sp., Apodolirion buchananii (Natal Crocus), Berkheya echinacea, Berkheya setifera (Buffalotongue Berkheya), Berkheya sp., Brunsvigia? undulata (Ruby Brunsvigia), Chlorophytum sp. (Chlorophytum), Clutia cordata (Grassland Clutia), Commelina africana (Yellow Commelina), Crotalaria dura (Wild Lucerne), Dierama nixonianum, Dierama reynoldsii (Hairbells, Wand-flowers), Eriosema cordatum (Heart-leaved Eriosema), Gladiolus longicollis (Honey Flower), Hebenstretia sp. (Katstert), Helichrysum acutatum (Sticky Everlasting), Helichrysum ecklonis, Heliophila rigidiuscula (Grassland Blue Cross Flower), Hesperantha baurii, Hilliardiella sp., Justicia Andromeda, Kniphofia laxiflora (Slender Poker), Leobordea pulchra, Moraea moggii, Orthochilus foliosus, Pentanisia prunelloides (Broad-leaved Pentanisia), Rabdosiella calycina (Uplands Fly Bush), Rhynchosia villosa (Giant Hairy-leaved Rhynchosia), Senecio glaberrimus, Tephrosia macropoda (Creeping Tephrosia), Trachyandra asperata and Watsonia densiplora (Natal Watsonia).

\section{Materials and methods}

Asilidae were sampled using a standard, hand-held, $30 \mathrm{~cm}$ diameter, $120 \mathrm{~cm}$ long entomological net. While walking, the vegetation was visually scanned (in order to spot larger, more active species) and swept with the net (in order to collect small species adapted for living within the vegetation) for an hour, one morning per week (usually on a Monday). While most of the Asilidae collected were merely identified, counted and released, a few representatives of each species were kept in order to verify identifications. Retained specimens were mounted, labelled and incorporated into the Diptera collection of the KwaZulu-Natal Museum, Pietermaritzburg, at the end of the survey.

Weather, being an important factor, was monitored, with care being taken to sample at more or less the same time of day (between 10:00 $\mathrm{h}$ and 14:00 h) and when the vegetation was dry. Sampling was not possible on 4 weeks of the year (weeks 4, 24, 29, 44) 

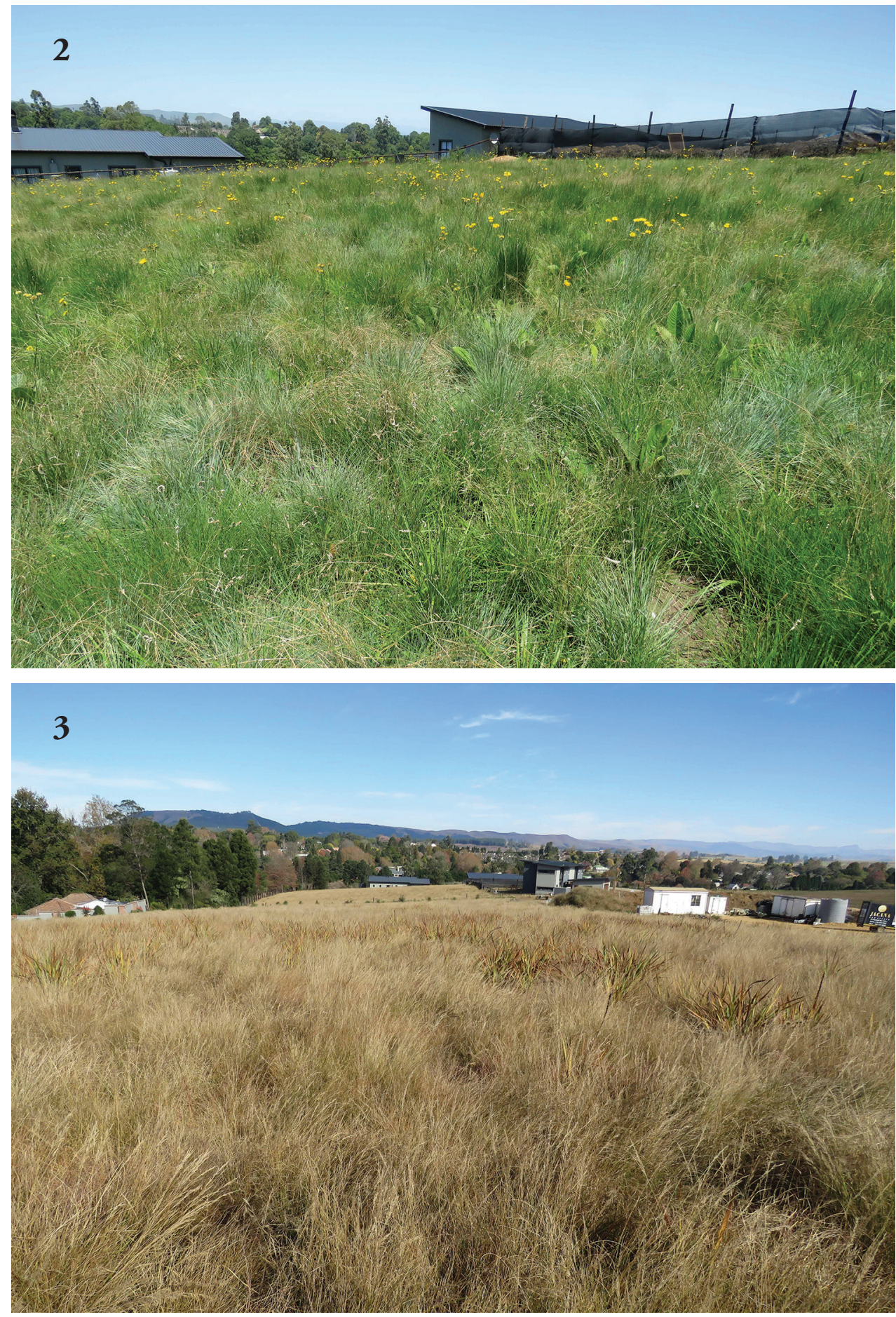

Figures 2, 3. Grassland at Jacana Eco Estate: $\mathbf{2}$ summer condition (week 51) 3 winter condition (week 25). Photos: JGH Londt. 
Table 2. Rainfall data (mm) for 2019 collected in Pietermaritzburg.

\begin{tabular}{ccccccccccccc}
\hline Jan & Feb & Mar & Apr & May & Jun & Jul & Aug & Sep & Oct & Nov & Dec & Total \\
\hline 93 & 143 & 82 & 116 & 26 & 0 & 2 & 19 & 34 & 39 & 199 & 126 & 979 \\
\hline
\end{tabular}

due to other commitments. On each occasion, a thermometer was used to record ambient temperature, which ranged from $15^{\circ} \mathrm{C}$ (week 26) to $33^{\circ} \mathrm{C}$ (week 41). The mean temperature for all sampling occasions was $23^{\circ} \mathrm{C}$. Figs 2, 3 provide impressions of the grassland in mid-summer (week 51) and mid-winter (week 25).

Care was taken to transect the entire length of the area, spending roughly the same time in the two adjacent fields on each sampling occasion. The distance covered on each occasion was approximately $1.5 \mathrm{~km}$ (measured with a pedometer). With the scheduled burning of the vegetation during weeks 35, 36 and 41, sweeping had to be confined to suitable vegetation and greater emphasis placed on visual sightings of ground inhabiting species until the vegetation had recovered sufficiently for more standardised sampling.

Although rainfall data was not available for the Jacana study site, Table 2 provides data collected in Pietermaritzburg, some $8.7 \mathrm{~km}$ from the site. A similar rainfall pattern, considered normal, was experienced at the study site during the survey.

\section{Results}

Eighteen species of Asilidae were collected during the year-long survey at Jacana (Table 3). These have been arranged in the order they were encountered. Comments on all the encountered species follow:

\section{Euscelidia vallis Dikow, 2003}

Fig. 9

Remarks. This species was positively identified by Dikow (pers com) who reviewed the extensive Afrotropical Euscelidia fauna, comprising over fifty species (Dikow 2003). The species was described, based on only three specimens, two from Mhlopeni Nature Reserve $\left(29^{\circ} 00^{\prime} \mathrm{S}, 30^{\circ} 25^{\prime} \mathrm{E}\right)$, collected in February and one from Van Reenen $\left(28^{\circ} 22^{\prime} \mathrm{S}\right.$, $29^{\circ} 23^{\prime} \mathrm{E}$ ) collected in January.

Adults of this species were encountered in large numbers on the first sampling day and the species remained abundant for the following 11 weeks before numbers began to decrease from week 12 . The species was poorly represented during weeks 13-15, before finally disappearing in week 16 . The species was not collected throughout winter and most of spring, but reappeared in moderate numbers on week 42 . The species was fairly common during weeks 42-47, before again being fairly abundant on week 48. For some unknown reason, the species suddenly disappeared from samples taken during weeks 49 and 50 before reappearing in low numbers on week 51 and in greater numbers on week 52 . 

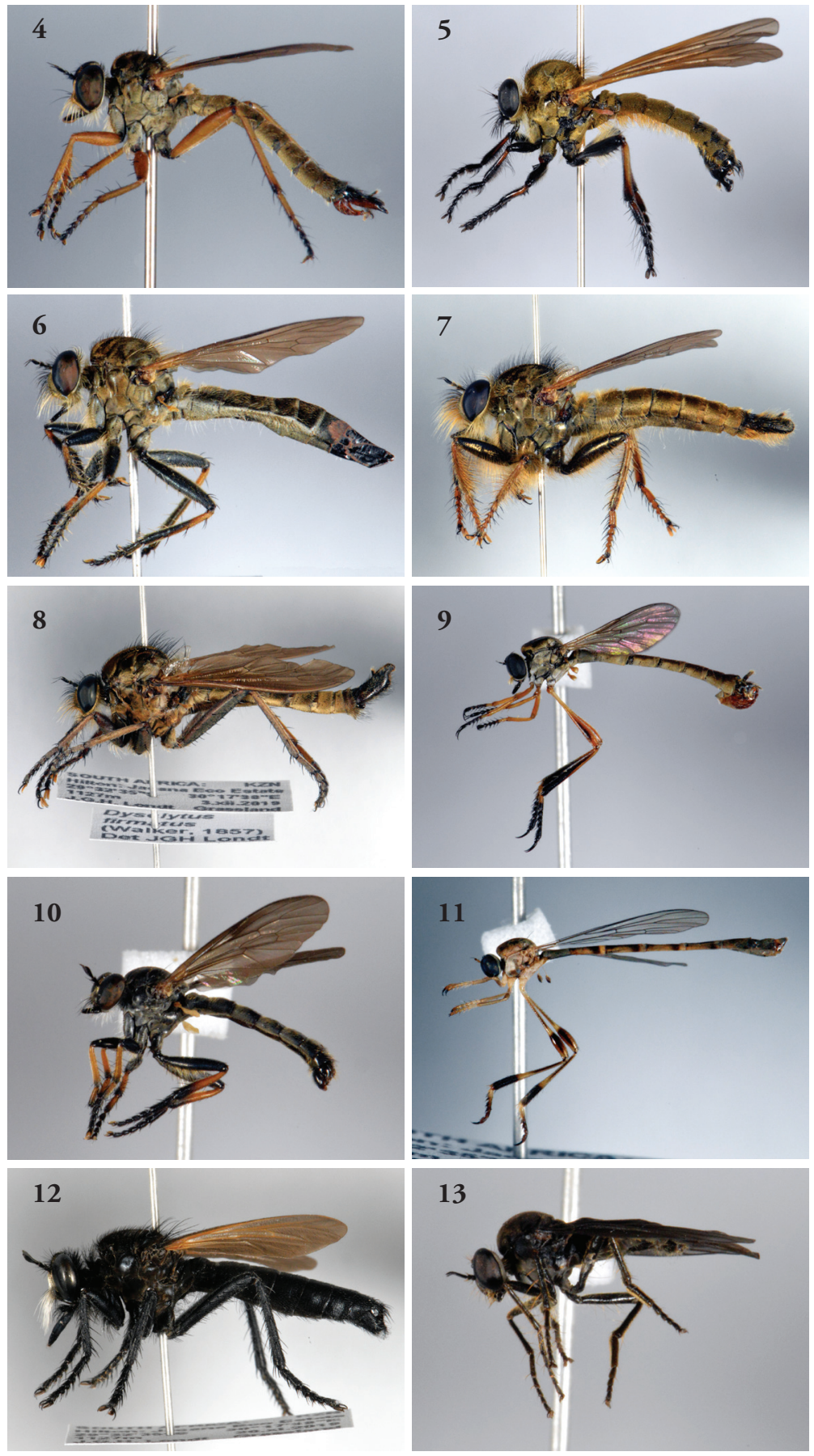

Figures 4-13. Grassland inhabiting Asilidae encountered at Jacana Eco Estate (arranged alphabetically): 4 Caenoura annulitarsis (Loew, 1858) 5 Damalis monochaetes Londt, 19896 Dasophrys fortis Londt, 1981 7 Dasophrys tarsalis (Ricardo, 1920) 8 Dysclytus firmatus (Walker, 1857) 9 Euscelidia vallis Dikow, 2003 10 Ischiolobos mesotopos Londt, 2005 I I Leptogaster sp. 12 Microstylum sp. 13 Rhipidocephala obscurata Oldroyd, 1966. Photos: B. Muller. 


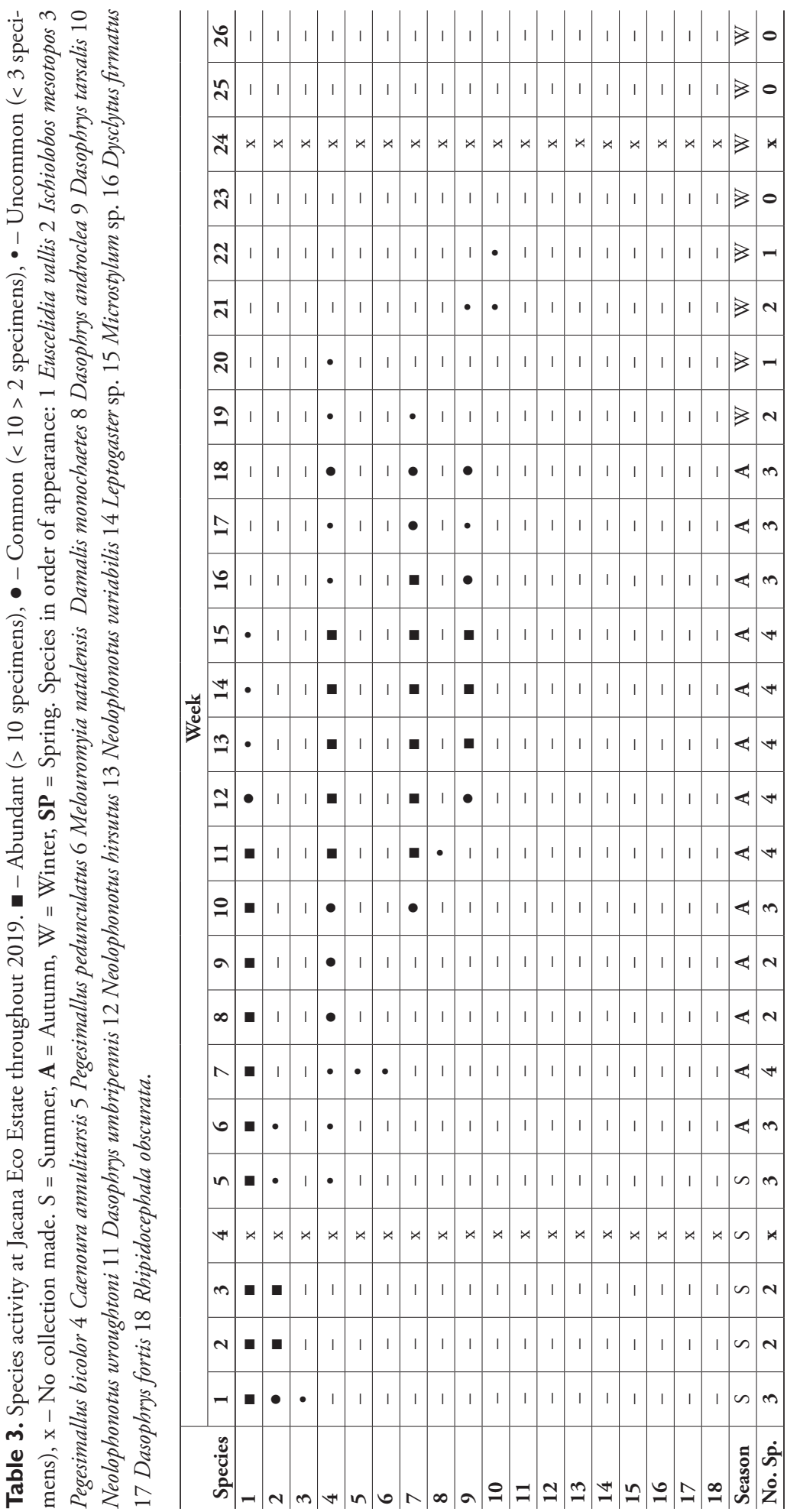




\begin{tabular}{|c|c|c|c|c|c|c|c|c|c|c|c|c|c|c|c|c|c|c|c|}
\hline ก & - & - & 1 & 1 & 1 & 1 & 1 & I & I & 1 & 1 & 1 & • & 1 & - & 1 & I & & 0 \\
\hline in & • & - & 1 & 1 & 1 & 1 & 1 & 1 & 1 & 1 & 1 & 1 & 1 & 1 & $\bullet$ & 1 & - & • & 0 \\
\hline in & 1 & - & 1 & 1 & 1 & 1 & 1 & 1 & 1 & 1 & 1 & 1 & 1 & 1 & $\bullet$ & 1 & 1 & 1 & 0 \\
\hline ફे & 1 & - & 1 & 1 & 1 & 1 & 1 & 1 & 1 & 1 & 1 & 1 & 1 & 1 & $\bullet$ & • & 1 & 1 & 0 \\
\hline$\stackrel{\infty}{\rightarrow+}$ & - & $\bullet$ & 1 & 1 & 1 & 1 & 1 & 1 & 1 & 1 & 1 & 1 & 1 & 1 & - & • & 1 & 1 & 0 \\
\hline$\Leftrightarrow$ & $\bullet$ & • & 1 & 1 & 1 & 1 & 1 & 1 & 1 & 1 & 1 & 1 & 1 & 1 & - & • & 1 & 1 & $0 \forall$ \\
\hline$\stackrel{i}{*}$ & • & $\bullet$ & 1 & 1 & 1 & 1 & 1 & 1 & 1 & 1 & 1 & 1 & • & 1 & - & • & 1 & 1 & 0 \\
\hline$\approx$ & $\bullet$ & • & 1 & 1 & 1 & 1 & 1 & 1 & 1 & 1 & 1 & 1 & • & 1 & - & 1 & 1 & & 0 \\
\hline $\mathbb{F}$ & $\star x$ & $\star x$ & $\star$ & $\star$ & $\star$ & $\star$ & $\star \star$ & $\star \star$ & $\star$ & $\star A$ & $\star$ & $\star$ & $\star x$ & $\star x$ & $\star x$ & $\star x$ & $\star$ & & $5 x$ \\
\hline$\stackrel{?}{\rightarrow}$ & $\bullet$ & 1 & 1 & 1 & 1 & 1 & 1 & 1 & 1 & 1 & 1 & 1 & $\bullet$ & 1 & 1 & 1 & I & & 5 \\
\hline F & $\bullet$ & 1 & 1 & 1 & 1 & 1 & 1 & 1 & 1 & 1 & 1 & 1 & $\bullet$ & 1 & 1 & 1 & 1 & & 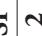 \\
\hline F & 1 & 1 & 1 & 1 & 1 & I & 1 & 1 & 1 & 1 & 1 & 1 & $\bullet$ & 1 & 1 & 1 & 1 & & $5-$ \\
\hline 아 & 1 & 1 & 1 & 1 & 1 & 1 & 1 & 1 & 1 & 1 & I & 1 & 1 & 1 & 1 & 1 & I & & 50 \\
\hline ले & 1 & 1 & 1 & 1 & 1 & 1 & 1 & 1 & 1 & 1 & 1 & • & - & 1 & 1 & 1 & 1 & & $\dot{b} \sim \sim$ \\
\hline$\stackrel{\infty}{m}$ & 1 & 1 & 1 & 1 & 1 & 1 & 1 & 1 & 1 & 1 & I & $\bullet$ & 1 & • & 1 & 1 & 1 & & 5 \\
\hline के & 1 & 1 & 1 & 1 & 1 & 1 & 1 & 1 & 1 & 1 & I & $\bullet$ & 1 & 1 & 1 & 1 & 1 & & - \\
\hline గin & 1 & 1 & 1 & 1 & 1 & 1 & 1 & 1 & 1 & 1 & I & - & • & 1 & 1 & 1 & 1 & & 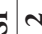 \\
\hline$\hat{n}$ & 1 & 1 & 1 & I & 1 & 1 & 1 & 1 & 1 & 1 & 1 & 1 & 1 & 1 & 1 & I & 1 & & 5 \\
\hline m & 1 & 1 & 1 & 1 & 1 & 1 & 1 & 1 & 1 & 1 & 1 & 1 & 1 & 1 & 1 & 1 & 1 & & 0 \\
\hline mे & 1 & 1 & 1 & 1 & 1 & 1 & 1 & 1 & 1 & 1 & 1 & 1 & 1 & 1 & 1 & 1 & 1 & & 50 \\
\hline กี & 1 & 1 & 1 & 1 & 1 & 1 & 1 & 1 & 1 & 1 & I & 1 & 1 & 1 & 1 & 1 & I & & 0 \\
\hline $\bar{m}$ & 1 & 1 & 1 & 1 & 1 & 1 & 1 & 1 & 1 & 1 & I & 1 & 1 & 1 & 1 & 1 & 1 & & 30 \\
\hline के & 1 & 1 & 1 & 1 & 1 & 1 & 1 & 1 & 1 & 1 & I & 1 & 1 & 1 & 1 & 1 & 1 & & 30 \\
\hline సิ & $\not$ & $\star x$ & 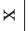 & $\not$ & $\not$ & $\not x$ & $\not$ & $\star$ & $\star A$ & $\star x$ & $x$ & 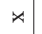 & $x$ & $x$ & $\star$ & $\not$ & $\star$ & & 36 \\
\hline$\stackrel{\infty}{\sim}$ & 1 & 1 & 1 & 1 & 1 & 1 & 1 & 1 & 1 & 1 & • & I & 1 & 1 & 1 & 1 & 1 & & $3-$ \\
\hline 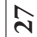 & 1 & 1 & 1 & 1 & 1 & 1 & 1 & 1 & 1 & 1 & I & 1 & 1 & 1 & 1 & 1 & 1 & & 30 \\
\hline $\mathscr{b}$ & & & & & & & & & & & $=$ & & 2 & -1 & & & & & 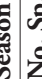 \\
\hline
\end{tabular}


Table 4. A comparison of Asilidae collected at two survey sites (species listed in the order collected at Jacana Eco Estate). Jacana data taken from Table 3 and Queen Elizabeth Park data from Fig. 4 of Londt (2002b). Weeks of activity calculated from both actual data and presumed occurrence when gaps in data occur. Weeks of activity (actual and presumed).

\begin{tabular}{lcc}
\hline \multicolumn{1}{c}{ Species } & Jacana Eco Estate & Queen Elizabeth Park \\
\hline Euscelidia vallis & $1-15,42-52(25$ weeks $)$ & $1-18,41-52(29$ weeks $)$ \\
Ischiolobos mesotopos & $1-6,45-52(14$ weeks $)$ & $1-16,52(17$ weeks $)$ \\
Caenoura annulitarsis & $5-20(16$ weeks $)$ & $1-20,48-52(25$ weeks $)$ \\
Dasophrus androclea & $11(1$ week $)$ & $18(1$ week $)$ \\
Neolophonotus wroughtoni & $21-22(2$ weeks $)$ & $20-36(17$ weeks $)$ \\
Leptogaster sp. & $38(1$ week $)$ & $10-16(7$ weeks $)$ \\
Microstylum sp. & $45-52(8$ weeks $)$ & $45-49(5$ weeks $)$ \\
Dasophrys fortis & $51(1$ week $)$ & $13(1$ week $)$ \\
Rhipidocephala obscurata & $51(1$ week $)$ & $3-5,48-52(8$ weeks $)$ \\
\hline
\end{tabular}

This species was, without doubt, the most commonly encountered species, especially in the upper field, during the survey, being present for some 26 weeks of the year.

This small species was invariably swept from long grass with very few actually being sighted. None were encountered mating or with prey. The species appears to be largely confined to Londt's (1994) ecological category 4a (within grass).

Material from Jacana has been compared with specimens collected during the Queen Elizabeth Park survey (Londt 2002b) and found to be conspecific. Table 4 provides a comparison of flight periods with those recorded from Queen Elizabeth Park. Adults were encountered at approximately the same time of year and flight periods ranged from 25 weeks at Jacana to 29 weeks at Queen Elizabeth Park.

\section{Ischiolobos mesotopos Londt, 2005}

Fig. 10

Remarks. This species was described mainly on a good series of specimens collected during the year-long survey of a grassland within Queen Elizabeth Park (29 $\left.34^{\prime} \mathrm{S}, 30^{\circ} 19^{\prime} \mathrm{E}\right)$, Pietermaritzburg, when it was identified merely as "Species X" (Londt 2002b). The only other recorded localities were Hilton $\left(29^{\circ} 32^{\prime} \mathrm{S}, 30^{\circ} 17^{\prime} \mathrm{E}\right)$, collected in November and Cumberland Nature Reserve (29 $\left.30^{\prime} \mathrm{S}, 30^{\circ} 30^{\prime} \mathrm{E}\right)$ collected in January and December.

Adults of this species were encountered in good numbers on the first sampling day and the species remained abundant for the following three to four weeks before numbers began to decrease in weeks five and six. From week seven through to week 44 , the species was absent, only reappearing in week 45 . By week 49 , the species was again fairly abundantly represented. The flight period of this species was therefore 14 weeks. The species appeared to be fairly uniformly distributed in both the upper and lower fields. 
This small species was invariably swept from long grass with very few actually being sighted. None were encountered mating or with prey. The species appears to be largely confined to Londt's (1994) ecological category 4a (within grass).

Table 4 provides a comparison of flight periods with those recorded from Queen Elizabeth Park (Londt 2002b). Adults were encountered at approximately the same time of year and flight periods ranged from 14 weeks at Jacana to 17 weeks at Queen Elizabeth Park.

\section{Pegesimallus bicolor (Loew, 1858)}

Remarks. This species was reviewed along with other Afrotropical species and recorded from a number of localities in KwaZulu-Natal and the Eastern Cape Province (Londt 1980). Amongst these localities was Otto's Bluff $\left(29^{\circ} 32^{\prime} \mathrm{S}, 30^{\circ} 22^{\prime} \mathrm{E}\right)$ which is not far from Jacana. Recorded material has been collected in March, April, November and December.

Only a single adult female of this species was collected in the first week of the survey. The genus is not commonly encountered in grassland situations, species generally preferring indigenous forests and their margins (Londt's (1994), ecological category 5b (tips of shrubs and bushes)).

Members of the genus are active fliers and so it is highly likely that the encountered specimen was moving from one suitable habitat to another or had been swept into the area by wind.

\section{Caenoura annulitarsis (Loew, 1858)}

Fig. 4

Remarks. This fairly widely-distributed grassland species was reviewed by Londt (2002a). Found mainly in KwaZulu-Natal, the species has also been recorded from the surrounding provinces of Eastern Cape, Free State and Mpumalanga, as well as the neighbouring countries of Lesotho and Zimbabwe. Londt (2002a) gives adult activity data that includes all months from November to May, based mainly on material gathered during a grassland survey undertaken in 2000 at Queen Elizabeth Park $\left(29^{\circ} 34^{\prime}\right.$ S, $30^{\circ} 19^{\prime} \mathrm{E}$ ) in Pietermaritzburg (Londt 2002b).

At Jacana, adults of this species were encountered in low numbers on week five of the survey. By week eight, numbers had increased and by week 11, the species was considered abundant. Numbers began to decline from week 16 and the species had disappeared by week 21 ; the total flight period of adults being 16 weeks. The species was more commonly encountered in the upper field.

This relatively small species was invariably swept from grass with very few actually being sighted. None were encountered mating or with prey. The species appears to be largely confined to Londt's (1994) ecological category 4a (within grass). 
Table 4 provides a comparison of flight periods with those recorded from Queen Elizabeth Park (Londt 2002b). Adults were encountered at approximately the same time of year, but flight periods ranged from 16 weeks at Jacana to 25 weeks at Queen Elizabeth Park.

\section{Pegesimallus pedunculatus (Loew, 1858)}

Remarks. This widely-distributed and commonly encountered Southern African species was reviewed along with other Afrotropical species and recorded from many South African localities, as well as some in the neighbouring countries of Mozambique, Namibia and Zimbabwe (Londt 1980). The species has been commonly encountered in the Pietermaritzburg area where it is also known to frequent suburban gardens and has been recorded from October through to April.

A single adult female of this species was collected in week seven of the survey. The genus is not commonly encountered in grassland situations, but generally prefers indigenous forests and their margins (Londt's (1994) ecological category 5b (tips of shrubs and bushes)). This species may also be commonly encountered in suburban gardens.

Members of the genus are active fliers and so it is highly likely that the encountered specimen was moving from one suitable habitat to another or had been swept into the area by wind.

\section{Melouromyia natalensis (Ricardo, 1919)}

Remarks. This widely-distributed and fairly commonly encountered Southern African species was reviewed by Londt (2002a). It has been recorded from KwaZulu-Natal, as well as provinces to the north, including Mpumalanga, Gauteng, Northwest Province and Limpopo. There are also records from Swaziland, Botswana and Zimbabwe. The species has been recorded from Pietermaritzburg and so there was no surprise encountering it at Jacana Eco-estate.

A single adult female of this species was collected in week seven of the survey.

Londt (2002a) reports the species as normally being associated with woodland habitats and has been collected in suburban gardens in Pietermaritzburg. Its occurrence in the Jacana Eco-estate's grassland is viewed as fortuitous.

\section{Damalis monochaetes Londt, 1989}

Fig. 5

Remarks. Damalus Fabricius, 1805, was revised by Londt (1989) who described monochaetes from material collected mainly in the midlands of KwaZulu-Natal, the holotype 
having been collected at the Doreen Clarke Nature Reserve (29³ $\left.34^{\prime} 41^{\prime \prime S}, 30^{\circ} 17^{\prime} 19^{\prime \prime} \mathrm{E}\right)$, not far from Jacana.

Adults of this species were first encountered, in moderate numbers, in week 10. The species then became abundant over the following six weeks (weeks 11-16). Numbers then diminished over the next three weeks (17-19) and none were encountered on and after week 20 . The species was almost entirely confined to the lower field in an area adjacent to trees bordering the estate (most species appear to inhabit vegetation adjacent to wooded areas).

This moderately sized, rather active species was almost invariably seen flying over the vegetation and was easy to catch. Although none were encountered with prey, tail-to-tail mating pairs were commonly observed. The species appears to be largely confined to Londt's (1994) ecological category 4b (grass tips).

\section{Dasophrys androclea (Walker 1849)}

Remarks. Afrotropical Dasophrys Loew, 1858 were revised by Londt (1981), with androclea being recorded from a number of localities in KwaZulu-Natal, including the Pietermaritzburg area where it is usually encountered in indigenous forest situations, as well as suburbia. A single specimen was collected during a grassland survey conducted at Queen Elizabeth Park (Londt 2002b) and so its occurrence at Jacana Eco Estate was not entirely unexpected.

A single adult male of this species was collected in week 11 of the Jacana survey.

Londt (1981) records the species as having been encountered during every month of the year except for August and September. Records and personal experience, suggest that the species is usually associated with woodland habitats, as well as suburban gardens in Pietermaritzburg. Its occurrence in the Jacana grassland is viewed as fortuitous as the species would probably best be placed in Londt's (1994) ecological category 5a (tips of shrubs and bushes) or 6 a (within trees).

Table 4 provides a comparison of flight periods with those recorded for Queen Elizabeth Park (Londt 2002b). While the single adult collected at Jacana was found in week 11, the species was recorded in week 18 at Queen Elizabeth Park, also based on a single specimen.

\section{Dasophrys tarsalis (Ricardo, 1920)}

Fig. 7

Remarks. Afrotropical Dasophrys Loew, 1858 were revised by Londt (1981), with tarsalis being recorded from a number of localities in KwaZulu-Natal, situated mainly in the so called 'midlands' which lie a short distance north-west of Hilton. However, the nearest recorded locality to Jacana is 'The Start', a stud farm ca. $20 \mathrm{~km} \mathrm{NE}$ of Howick (ca. $29^{\circ} 23^{\prime} 57^{\prime \prime S}, 30^{\circ} 17^{\prime} 21^{\prime \prime E}$ ). Its occurrence at Jacana Eco Estate was unexpected, but hardly surprising. 
Adults of this species were common to abundant between the late autumn weeks 12 and 18. None were encountered in weeks 19 and 20, while a single specimen was found in week 21 . All specimens were collected in the lower field.

This moderately large species was almost invariably encountered flying fairly close to the ground where individuals perched on low vegetation. None were encountered mating or with prey. The species appears to be largely confined to Londt's (1994) ecological category $4 \mathrm{a}$ (within grass). The female's laterally compressed ovipositor is probably an adaptation for oviposition in grass.

\section{Neolophonotus wroughtoni (Ricardo, 1920)}

Remarks. This species, a member of the large comatus species group, was reviewed by Londt (1988). The species, described on material from Willowgrange (ca. 2906'S, $29^{\circ} 57^{\prime} \mathrm{E}$ ) near Estcourt in KwaZulu-Natal, is fairly widely distributed throughout the eastern parts of southern Africa and has been collected in every month of the year except February. The species is common in Pietermaritzburg and surrounding area.

Only two specimens were collected during the winter at Jacana, one each on weeks 21 and 22, respectively. Adults were found resting on the ground and clearly belong to Londt's (1994) ecological category 1c (open ground). The fact that there is very little open ground at Jacana may explain the apparent rarity at this site.

Table 4 provides a comparison of flight periods with those recorded from Queen Elizabeth Park (Londt 2002b). While the species was only encountered on weeks 2122 at Jacana, it was encountered between weeks 20 and 36 at Queen Elizabeth Park. The difference may be due to the fact that there was more open ground at Queen Elizabeth Park, mainly in the form of pathways.

\section{Dasophrys umbripennis Londt, 1981}

Remarks. This species was originally described mainly from the Pietermaritzburg district (Londt 1981).

A single adult male was collected in week 28 .

This distinctive species was swept from long grass. Its patterned wings are almost certainly an adaptation to forest or forest margin habitats, i.e. Londt's (1994) ecological category $5 \mathrm{~b}$ (within shrubs and bushes) and so the Jacana specimen was certainly out of its previously recorded 'preferred' habitat.

\section{Neolophonotus hirsutus (Ricardo, 1920)}

Remarks. This species, reviewed by Londt (1988), is currently a KwaZulu-Natal endemic, apparently limited largely to higher altitude areas of the province. Its near- 
est recorded locality to Jacana is the Umgeni Valley Nature Reserve (ca. 29 $28^{\prime} 32^{\prime \prime S}$, $\left.30^{\circ} 14^{\prime} 21^{\prime \prime} \mathrm{E}\right)$ on the outskirts of Howick.

Adults of this species were encountered in low to moderate numbers during the four spring weeks 36-39. All encountered individuals were found in the lower field, especially in areas that had recently been burned.

This small to medium-sized species was invariably found resting on the ground or on vegetation close to the ground. While two specimens were collected with Diptera prey, others were swept from long grass with very few actually being sighted. The species appears to be largely confined to Londt's (1994) ecological category 1c (open ground).

\section{Neolophonotus variabilis Londt, 1986}

Remarks. This somewhat variable species, a member of the suillus species group, was described using many specimens collected mainly in KwaZulu-Natal, but also recorded from various localities in the Eastern and Western Cape provinces (Londt 1986), most being at relatively high altitudes. While not previously recorded from Hilton or Pietermaritzburg, the closest recorded localities are Bulwer (ca. 2948'27"S, 2945'36"E) and New Hanover (ca. 29²1'08"S, 30³1'26"E).

Single specimens were collected at Jacana in weeks 36 and 39, fair numbers were then encountered in weeks 41-45 and a single specimen was collected in week 46 . Although the species was not encountered in weeks 47-51, a single specimen was netted in week 52. Although the flight period spanned some 17 weeks (from week 36 to 52 ), the species appeared to be most active in late spring between weeks $41-45$. All encountered individuals were found in the lower field.

This species was usually observed resting on the ground or on vegetation close to the ground and is considered belonging to Londt's (1994) ecological category 1c (open ground). None were found with prey.

\section{Leptogaster sp.}

Fig. 11

Remarks. Leptogaster Meigen, 1803 is a large genus, with over 50 described Afrotropical species, that is in need of modern revision (Londt and Dikow 2017). There are many unidentified southern African specimens in the KwaZulu-Natal Museum's collection and in other collections around the globe. The Jacana species cannot be identified specifically at present. Londt (2002b) recorded a species as occurring at Queen Elizabeth Park which was tentatively identified as 'sp. 1 near maculipennis Janssens, 1957'.

A single male specimen, requiring specific identification, was collected in Jacana's upper field on week 38 of the survey.

This small species was swept from long grass and is considered to belong to Londt's (1994) ecological category 4 a (within grass). 
A comparison of material from Jacana and Queen Elizabeth Park strongly suggests that only a single species is involved. While Table 4 provides a comparison of the recorded flight periods, these do not appear to overlap.

\section{Microstylum sp.}

Fig. 12

Remarks. Microstylum Macquart, 1838, with 90 catalogued Afrotropical species, 79 listed as valid and 11 as synonyms (Oldroyd 1980), is in great need of modern revision. Oldroyd (1980) lists 39 species as occurring in South Africa alone and so a revision of these large and impressive flies is seen as a high priority. In the absence of any modern keys, no specific name can even be suggested for the species encountered at Jacana. A very similar looking species was collected during a grassland survey undertaken at Queen Elizabeth Park in Pietermaritzburg (Londt 2002b).

Adults of this summer active species were encountered in large numbers from week 45 through to week 48 when numbers declined. The species was 'uncommon' in week 52 , the last week of the survey, with only a single specimen being seen and captured.

This large, almost entirely black species was invariably seen flying strongly over the vegetation, mainly in the lower field. Although a number of mating pairs were encountered, none were observed feeding. The species appears to be best accommodated within Londt's (1994) ecological category 4 b (grass tips).

Although Table 4 provides a comparison of flight periods with those recorded for a species collected at Queen Elizabeth Park (Londt 2002b), a comparison of specimens does not provide sufficient evidence to suggest that these species are conspecific. However, the flight periods were remarkably similar, being weeks 45-52 at Jacana and weeks 45-49 at Queen Elizabeth Park (note that no sampling was undertaken on weeks 50 and 51 of the Queen Elizabeth Park survey).

\section{Dysclytus firmatus (Walker, 1857)}

Fig. 8

Remarks. Dysclytus Loew, 1858, is currently monotypic, with firmatus being considered the only valid species. In his handling of the genus, Londt (1979) records the species from only two relatively small areas, one in KwaZulu-Natal Province (Durban, Isipingo and Tongaat) and the other in eastern Mpumalanga Province (Ngondwana (= Ngodwana), Kaapsehoop, Waterval Onder and Elandshoek). Although a few more recently collected specimens are to be found in the KwaZulu-Natal Museum's collection, none have previously been collected in the Hilton or Pietermaritzburg area.

Adults of this species had a relatively short period of activity in summer, being encountered in fair numbers in weeks 46-48, while a single specimen was collected in week 49. The species was invariably encountered in the lower field. 
This fairly large and distinctive species was almost invariably seen flying over or between grass clumps and coming to rest on vegetation. While none were encountered mating, one female was collected with prey, a small cicada (Cicadidae). The species appears to be largely confined to Londt's (1994) ecological category $4 \mathrm{~b}$ (grass tips). The female's laterally compressed ovipositor suggests oviposition in grass.

\section{Dasophrys fortis Londt, 1981}

Fig. 6

Remarks. Londt (1981) revised the genus and provided a key for the identification of species. However, the key requires male specimens. Although the single female, swept from grass in week 51 of the survey, cannot be keyed out confidently, its rather short ovipositor (length:breadth ratio ca. 2.3) suggests that it belongs to the grassland species D. fortis Londt, 1981. For the present, this Jacana female will be assigned to D. fortis until this identification can be disproved.

This female is almost certainly confined to Londt's (1994) ecological category 4a (within grass). Table 4 provides a comparison of flight periods with those recorded from Queen Elizabeth Park (Londt 2002b) where it was only collected on week 13.

\section{Rhipidocephala obscurata Oldroyd, 1966}

Fig. 13

Remarks. Oldroyd (1966) reviewed the genus and later (1980) catalogued 26 then considered valid species, together with three listed as synonyms. Material collected during the Queen Elizabeth Park survey was keyed out to $R$. obscurata, an identification that needs confirmation.

Although a single female, swept from grass on week 51 of the Jacana survey, keys out to $R$. obscurata using Oldroyd's (1966) key, the identification may be questionable as Oldroyd's types all come from the Kariba area (ca. $\left.16^{\circ} 31^{\prime} \mathrm{S}, 28^{\circ} 51^{\prime} \mathrm{E}\right)$ in Zimbabwe.

The species is probably confined to Londt's (1994) ecological category 4a (within grass) or $4 \mathrm{~b}$ (grass tips).

Table 4 provides a comparison of flight information for both the Jacana and Queen Elizabeth Park (Londt 2002b) surveys. While the only encountered Jacana specimen was collected on week 51, the species was recorded over an eight week period, between weeks 3-5 and 48-52, at Queen Elizabeth Park.

\section{Discussion}

Eighteen species of Asilidae were encountered at Jacana, two fewer than recorded during an earlier survey at Queen Elizabeth Park (Londt 2002b). While some of these 
species are more commonly associated with forests and their margins, the majority are clearly restricted to the grassland biome. The fact that Asilidae are predators and, therefore, rely on healthy populations of insect prey, suggests that the relatively unspoiled grasslands surveyed can be considered reasonably well managed. Clearly, comparative surveys involving spoiled and rehabilitated grasslands would further add to a better understanding of the value of assessments of the kind reported in this publication.

Although 18 species were encountered during the survey, the largest number encountered on any one occasion was five, less than a third of the species inhabiting the area. It is, therefore, obvious that a proper understanding of the invertebrate fauna of any particular locality probably requires a number of strategically planned sampling occasions.

Of particular interest, but not unexpected, is the fact that very few Asilidae were encountered during winter (weeks 19-31) and early spring (weeks 32-35). The planned burning of the grassland which took place during the spring weeks of 35, 36 and 41 appears to have had little impact on asilid populations. While some ground inhabiting species of Neolophonotus were encountered in spring and the emergence of E. vallis, a dominant grass inhabiting species, commenced on week 42 , the burning of the grassland did not appear to have any significant impact on asilid life cycles. However, the fact that $E$. vallis began emerging at the time of the last burn (week 41) strongly suggests that earlier burns, timed with the end of winter or start of spring, would be preferable.

Also of interest was the fact that some species appeared to be mostly confined to either the upper or lower fields. The upper field, being larger, higher and more exposed may be more suitable for some species while the lower field, being lower and more protected by bordering trees may offer more suitable environmental conditions for other species. Another possible factor which may be of importance is the existence of the access road that separates the fields. This roadway, which has been lined with trees, may well constitute a barrier restricting dispersal between the two fields. Efforts to minimise the possible impact of this access road should be contemplated.

While a more detailed comparison of the results obtained during the survey of Queen Elizabeth Park (Londt 2002b) and Jacana Eco Estate could prove interesting, this would only be feasible when far more is known about the specific environmental requirements of each asilid species involved. Although Queen Elizabeth Park is only five kilometres south-east of Jacana Eco Estate and experiences similar weather patterns, Jacana Eco Estate, with an altitude of over $1100 \mathrm{~m}$, is some $200 \mathrm{~m}$ higher than the site at Queen Elizabeth Park which lies at approximately $900 \mathrm{~m}$. There are likely to be significant differences in the botanical characteristics of the two sites and these would almost certainly impact on the composition of the asilid faunas involved. In the absence of such information, comparisons of any kind would be tenuous at best.

\section{Acknowledgements}

Paul Kotze, developer of the Jacana Eco Estate, is thanked for allowing me to undertake regular visits to the estate and for providing me with some of the documentation issued before the development commenced. With his permission, Julie Dakers of 
Catchway Properties (Pty) Ltd kindly supplied me with architectural plans and aerial photos of the estate. Drs John Midgley and Kirstin Williams of the KwaZulu-Natal Museum, Pietermaritzburg, provided unlimited access to collections and associated services, for which I am grateful. Burgert Muller (National Museum, Bloemfontein) kindly generated the map of the estate and photographs of Asilidae. Alison Young (Botany Department, University of KwaZulu-Natal, Pietermaritzburg), is thanked for undertaking identifications of plants encountered at Jacana during the survey. Financial support was kindly provided by both the University of KwaZulu-Natal and the Foundation for Research Development. The continued support and encouragement of my wife Ann is also appreciated.

\section{References}

Dikow T (2003) Revision of the genus Euscelidia Westwood, 1850 (Diptera: Asilidae: Leptogastrinae). African Invertebrates 44(2): 1-131.

Grobler JH (2007) Bracken Ridge Development (Hilton Erf. 330) Pietermaritzburg. Biodiversity Assessment. Not formally published, $24 \mathrm{pp}$.

Londt JGH (1979) The genus Dysclytus Loew (Diptera: Asilidae). Journal of the Entomological Society of Southern Africa 42(2): 217-223.

Londt JGH (1980) Afrotropical Asilidae (Diptera) 4. The genus Pegesimallus Loew, 1858 (= Lagodias Loew, 1858; Neolaparus Williston, 1889) including species from other zoogeographical regions and the descriptions of two new genera Brevirostrum and Caroncoma. Annals of the Natal Museum 24(1): 233-347.

Londt JGH (1981) Afrotropical Asilidae (Diptera) 5. The genus Dasophrys Loew, 1858 (= Hobbyus Bromley, 1952) (Asilinae: Asilini). Annals of the Natal Museum 24(2): 635-699.

Londt JGH (1986) Afrotropical Asilidae (Diptera) 13. The genus Neolophonotus Engel, 1925. Part 2. The suillus species-group (Asilinae: Asilini). Annals of the Natal Museum 27(2): 513-600.

Londt JGH (1988) Afrotropical Asilidae (Diptera) 15. The genus Neolophonotus Engel, 1925. Part 4. The comatus species - group (Asilinae: Asilini). Annals of the Natal Museum 29(1): $1-166$.

Londt JGH (1989) Afrotropical Asilidae (Diptera) 17. The genus Damalis Fabricius, 1805 in subsaharan Africa (Trigonomiminae). Annals of the Natal Museum 30: 53-145.

Londt JGH (1994) Afrotropical Asilidae (Diptera) 26. Ethological observations, and a possible ecological classification based on habitats. Annals of the Natal Museum 35: 97-122.

Londt JGH (2002a) Afrotropical Asilinae (Asilidae): A provisional key to genera, with a review of the status of Neomochtherus Osten Sacken, 1878, and descriptions of new genera and species. African Invertebrates 43: 11-92.

Londt JGH (2002b) A survey of grassland Asilidae (Diptera) at Queen Elizabeth Park, Pietermaritzburg, South Africa. African Invertebrates 46: 203-252.

Londt JGH, Dikow T (2017) 48. Asilidae (Robber Flies or Assassin Flies). In: Kirk-Spriggs AH, Sinclair BJ (Eds) Manual of Afrotropical Diptera. Volume 2: Nematocerous Diptera and lower Brachycera. Suricata 5. SANBI, Pretoria, 1097-1182. 
Oldroyd H (1966) The genus Rhipidocephala (Diptera: Asilidae). Bulletin of the British Museum Natural History (Entomology) 18: 143-172.

Oldroyd H (1980) Family Asilidae. In: Crosskey RW (Ed.) Catalogue of the Diptera of the Afrotropical Region. British Museum (Natural History), London, 334-373, 1218, 1226, 1229.

Pooley E (1998) A Field Guide to Wild Flowers KwaZulu-Natal and the Eastern Region. Natal Flora Publications Trust, 630 pp.

Van Oudtshoorn F (1999) Guide to Grasses of Southern Africa. Briza Publications Cc, 288 pp.

Van Wyk AE, Smith GF (2001) Regions of Floristic Endemism in Southern Africa. Umdaus Press, Harfield, South Africa. 